\title{
School Library Learning Environment Assessment in International Schools
}

\author{
Barbara Schultz-Jones, Ph.D., Associate Professor \\ College of Information, University of North Texas, 1155 Union Circle 311068, Denton, \\ Texas 76203-5017 United States \\ Telephone: 1-940-369-8081 \\ E-mail: Barbara.Schultz-Jones@unt.edu
}

Betty Turpin, MS, Teacher Librarian

International School of Stuttgart, Germany

E-mail: turpinb@issev.de

Cynthia Ledbetter, Ph.D., Professor Emeritus

Science/Mathematics Education Department, University of Texas at Dallas, 800 West

Campbell Rd., FN32, Richardson, TX 75080-0688 United States

E-mail: ledbetter@utdallas.edu

\begin{abstract}
Evidence of how an assessment of the learning environment in an international school library equips the teacher librarian with valuable data that may challenge assumptions of how the learning environment is perceived by students is presented through disclosure of the full results of a two year research study examining the application of a learning environment paradigm to the lower school library setting in an international school in Germany. The process of completing a comparative examination of the relationships among student perceptions of their lower school library program with grade levels Third (ages 8 and 9), through Five (ages 10 and 11) is detailed. In addition, the assessment instruments will be discussed and presented. Use of these instruments in this study of the psychosocial aspects of the learning environment offers valuable ideas and techniques for teacher librarian consideration and development.

\section{Introduction}

In education we are seeing a considerable shift from teacher-centered to studentcentered learning environments, the inclusion of digital technology in the curriculum, investigative problem solving and inquiry based research. Assessment of the learning environment in a school library equips the teacher librarian with valuable data that may challenge assumptions of how the learning environment is perceived by students.

Additionally, the data can be used to correlate dimensions of the school library learning environment with gender differences, previous educational experience, librarian support, teacher support, ethnic background, and number of languages spoken.

The school library learning environment is a dynamic domain where dedicated professionals engage students in an active and evolving educational climate that strives to transform and influence student lives and achievement. Identifying the aspects of this domain and the outcomes of the relationship between school libraries and student achievement
\end{abstract}


reflects the nascent focus on evidence based school librarianship (Todd, 2009). Central to evidence based education systems is an emphasis on scientifically-based research that is welldesigned and implemented. The focus on student achievement also demands rigorous applications that demonstrate Todd's "three central dimensions of evidence based education: evidence for practice (research foundation), evidence in practice (research integration, and evidence of practice (student learning impacts)" (p. 82). With this challenge in mind, the current research draws on an existing body of classroom learning environment research and integrates this research into an examination of the school library learning environment in a German international school.

International schools offer a variety of definitions and contexts. For this project, an international school is defined as a K-12 educational institution which offers an English-based curriculum. Currently there are 6,255 international schools in 236 countries around the world (ISC Research, 2010). International schools may offer a British, American, Canadian or Australian curriculum, a hybrid curriculum, or may be affiliated with the International Baccalaureate Organization and offer the Primary Years, Middle Years, or Diploma Programmes. These schools can be either for profit or not-for profit, secular or affiliated with a religious organization, supported by a corporation or the government, or financially independent. They may also be part of a multi-school system or a stand-alone organization. Factors which may be unique to international school libraries include:

- There may be an unusually high degree of differing expectations among patrons and user groups. Students, parents, and staff members have come from all over the world and experienced a wide variety of school libraries. They may expect much more than is on offer, or they may have been accustomed to much less. Thus, varying expectations of user groups is a factor which should be taken into account in all programs and planning.

- There may be a much higher percentage of language learners in the school. Whether the students are learning English or learning the language of the host country, students with developing language skills are present in much higher proportion than in a school library within a national school system.

- There may be a high percentage of student turn over, where the amount of student homogeneity in attendance for all of grades k-12 is very low. The clientele of international schools includes families that are highly mobile and as a result may include "third culture kids": children who have spent a significant part of his or her development years outside the parents' culture and develop a lifestyle of relationships to all of the cultures while not having full ownership in any ( Pollock \& Van Reken, p. 19).

- The collection will develop based on the characteristics and needs of the primary user groups. In international schools, this often means that the collection may be more heavily:

○ Multilingual, including mother tongue collections

- Multicultural, to reflect as many of the cultures present in the school as possible.

- Used to support the curriculum. Schools which do not offer a standardized curriculum rely heavily on the library collection to directly support teaching and learning, particularly in a "no textbook" scenario. 
- Skewed towards "easier" materials. A larger percentage of beginning level materials is often needed in schools where the majority of students are learning English alongside learning the curriculum.

With these distinguishing factors, the learning environment offered by the school library may be challenging. Nevertheless, educational goals provide the purpose of school library focus and support for an engaging and stimulating learning environment.

\section{Theoretical Framework}

Theoretically, the study was grounded on the constructivist point of view that learning environments are individual "constructions" (Tobin \& Fraser, 1998, p. 626) which are neither independent from, nor external to their participants (Lorsbach \& Basolo, 1998). Lorsbach and Basolo state that students and teacher simultaneously contribute to the creation of their learning environment; they interact within it and individually perceive it as observers. This view emphasizes the importance of student and teacher perceptions in the study of learning environments. These perceptions reflect one's personal interpretation and beliefs of the degree to which the physical and social setting of a class permits or hinders learning.

The aspect of learning environment research which focuses on conceptualizing, assessing and investigating how classroom participants perceive the socio/psychological aspects of their learning environment, has received significant attention over the past 30 years and has been used to evaluate educational reforms (Dryden \& Fraser, 1998; Taylor, Fraser \& Fisher, 1997). Assessing how school library participants perceive the socio/psychological aspect of their learning environment has been studied recently (Schultz-Jones \& Ledbetter, 2009, 2010a, 2010b) and draws on the foundation of learning environment research established for the classroom, with emphasis on the science classroom. The focus on inquiry by the science classroom and the school library suggests that the classroom learning environment research as evidence for practice could be extended to the school library.

The context for learning environment research uses the following definition:

"Learning environment refers to the social, psychological and pedagogical contexts in which learning occurs and which affect student achievement and attitudes" (Fraser, 1998a, p. 3). The consideration of a classroom's learning environment built on the foundational work of Lewin (1936) and Murray (1938) and advanced with the development of evaluation instruments. As research on classroom learning environments continued to grow, the number of evaluation instruments increased in Western and non-Western countries (Fraser, 2002, 2007). These instruments have been used in several research studies reviewed by Fraser (1998b; 1998c), including investigations of associations between learning outcomes and classroom environments (McRobbie \& Fraser, 1993) and the evaluation of educational innovations (Ogbuehi \& Fraser, 2007; Maor \& Fraser, 1996; Martin-Dunlop \& Fraser, 2008; Monsen \& Frederickson, 2004). Despite documented efforts of the positive relationship between school library media programs and student achievement (Lance, K.C., HamiltonPennell, C., Rodney, M.J., Peterson, L., \& Sitter, C. 2000; Lance, Rodney \& HamiltonPennell, 2000a, 2000b, 2001, 2002; Lance, Welborn \& Hamilton-Pennell, 1997; Smith, 2001, Todd \& Kuhlthau, 2004), an examination of the context within which learning occurs in the school library had not included an application of the learning environment paradigm for assessment. Prior to 2009, these instruments had not been used in a school library setting. 
For the purposes of this study two newly developed instruments were selected because they are based on a psychological view of learning that focused on students as coconstructors of their own knowledge (Goh, Young \& Fraser, 1995; Fraser \& O'Brien, 1985) and were developed for the school library environment. The questionnaires have two distinct applications: student assessment of the preferred learning environment and student assessment of the current learning environment. Both instruments reflect the classification of scales according to Moos' (1974) scheme for classifying human environments into the three basic dimensions of Relationship (the nature and intensity of personal relationships within the environment, the extent to which people are involved in the environment and support and help each other), Personal Development (basic directions along which personal growth and selfenhancement tend to occur), and System Maintenance and System Change (extent to which the environment is orderly, clear in expectations, maintains control and is responsive to change)(Fraser, 1998c).

The How My Library Supports Inquiry (HMLSI) questionnaires were developed to evaluate student perceptions of student learning in an inquiry-based school library learning environment and the effect of this environment on student literacy and by extension, the social good (Schultz-Jones \& Ledbetter, 2012). Each uses 28 items comprising seven scales to measure students' perceptions of the degree to which certain psychosocial factors are prevalent in the school library: reflection, librarian support, involvement, investigation, task orientation, cooperation, and equity. These dimensions relate to and support the development of inquiry based learning and a constructivist learning environment. The factor structure, internal consistency reliability, discriminant validity, and the ability to distinguish between different classes and groups were supported for both instruments. Validation of these instruments used data from a Texas study of 872 elementary students and 639 secondary students, principal components factor analysis with varimax rotation and Kaiser normalization to confirm the a priori structure of the questionnaires.

The HMLSI instruments were further adapted to accommodate data collection in an international school setting by clarifying potentially ambiguous language in recognition of the wide range of English language fluency across the grade levels. Incorporation of these instruments contributes a unique design for consideration of a variety of school library contexts within the burgeoning field of learning environments research (Nix, Ledbetter, \& Fraser, 2001). Since the school library provides a learning environment for the development of inquiry skills to advance student achievement, regardless of national location, the application of these assessment tools to the international school library context is worth examination. Further, this study of psychosocial aspects of the learning environment offers potentially valuable ideas for incorporation by school librarians and by extension the teachers with whom they collaborate. Much of the learning environment research focuses on the perception of a learning environment and the extent to which this perception matches what is preferred by students. There is a gap in the literature, however, on efforts to use this research as an assessment tool that can be used to transform a learning environment. With this research study we propose to move the focus on perception to transformation in an international school library setting.

\section{Research Setting}

The research setting is an international school, located in Germany. The school is an International Baccalaureate (IB) World School authorized to deliver all three IB 
programmes to a co-educational student body of over 600 students from over 45 countries. Three Library Media Centers (LMCs) serve the school community at two campuses. This research focuses on students at the main campus with access to the Lower School LMC - the satellite campus was not included. The Lower School LMC supports students and teachers from Prekindergarten through Grade 5 and the Secondary School LMC supports students and teachers in Grades 6-12. Both libraries offer and maintain print and digital resources. The Lower School LMC in this study has a mixed scheduling plan. Classes are booked on a fixed timetable each week for book exchange, but classes taught by the teacher librarian are arranged as needed through collaborative planning with classroom teachers. Students in Early Years through Grade 2 typically have story time or literature extensions while students in Grades 3-5 do more work with reference materials, the research process, and information literacy skills. Table 1 details the demographic makeup of the lower school's students.

Table 1:Lower school demographic student data

\begin{tabular}{|c|c|c|c|c|c|}
\hline $2010-2011$ & \multicolumn{2}{|c|}{ Gender } & \multicolumn{3}{c|}{ Number of } \\
\hline Grades & Female & Male & Languages & Home Countries & School last attended \\
\hline 3 & 19 & 17 & & & \\
\hline 4 & 24 & 14 & & & \\
\hline 5 & 21 & 19 & & & \\
\hline Subtotal & 64 & 50 & & & \\
\hline Total & \multicolumn{2}{|c|}{114} & 41 & 36 & \\
\hline $2011-2012$ & \multicolumn{7}{|l}{} \\
\hline 3 & 16 & 16 & & & \\
\hline 4 & 12 & 16 & & & \\
\hline 5 & 16 & 16 & & & 53 \\
\hline Subtotal & 44 & 48 & & & \\
\hline Total & 92 & 42 & 36 & \\
\hline
\end{tabular}

\section{Methods}

The research study began in the 2010/2011 school year with the delivery of two surveys, based on the validated instrument used in U.S. schools to 114 students. Two classes of students in each of grades three, four and five in the lower school were surveyed in two phases. First, they were asked a series of demographic questions including: the name of the school attended last year, home country, the number of languages spoken, and the preferred language. Then, the surveys delivered 28 questions within seven dimensions of the learning environment: reflection, librarian support, involvement, investigation, task orientation, cooperation, and equity. The questions asked what they would prefer to have happening in their school library learning environment and offered three choices: almost always, sometimes, and almost never. Several weeks later, the students were surveyed again to query what is actually happening within those seven dimensions.

Delivery of the first set of surveys resulted in feedback regarding the word structure of survey questions. Some students experienced difficulty understanding the questions and needed assistance to complete the surveys. The survey language was modified for clarity, as a result of this feedback (see Table 2 for an example), and a second round of research continued 
in the 2011/2012 school year with 92 participating students. In this second year students in two classes in each of grades three, four and five from the lower school were once again engaged in data collection.

Table 2: Instrument revision example for HMLSI Preferred

\begin{tabular}{|c|c|}
\hline \multicolumn{2}{|c|}{ Librarian Support } \\
\hline & In a perfect school library: \\
\hline The librarian would discuss things with me. & The librarian would talk with me. \\
\hline $\begin{array}{l}\text { The librarian would be interested in my } \\
\text { research questions. }\end{array}$ & $\begin{array}{l}\text { The librarian would be interested in my } \\
\text { questions. }\end{array}$ \\
\hline $\begin{array}{l}\text { The librarian would move about the library to } \\
\text { talk with me. }\end{array}$ & $\begin{array}{l}\text { The librarian would move around the } \\
\text { library to talk with me. }\end{array}$ \\
\hline $\begin{array}{l}\text { The librarian's questions would help me to } \\
\text { understand what I am looking for. }\end{array}$ & $\begin{array}{l}\text { The librarian's questions would help me to } \\
\text { understand what I am looking for. }\end{array}$ \\
\hline \multicolumn{2}{|c|}{ Investigation } \\
\hline & In a perfect school library: \\
\hline $\begin{array}{l}\text { I would be able to investigate questions that } \\
\text { puzzle me in the library. }\end{array}$ & $\begin{array}{l}\text { I would be able to ask questions that puzzle } \\
\text { me. }\end{array}$ \\
\hline $\begin{array}{l}\text { I would be able to investigate answers to the } \\
\text { teacher's questions in the library. }\end{array}$ & $\begin{array}{l}\text { I would be able to look for answers to the } \\
\text { teacher's questions. }\end{array}$ \\
\hline $\begin{array}{l}\text { I would be able to find out answers to } \\
\text { questions by doing investigations in the library. }\end{array}$ & $\begin{array}{l}\text { I would be able to find out answers to } \\
\text { questions by doing research. }\end{array}$ \\
\hline $\begin{array}{l}\text { I would be able to solve problems by using } \\
\text { answers I found in my own investigations in } \\
\text { the library. }\end{array}$ & $\begin{array}{l}\text { I would be able to solve problems by using } \\
\text { answers I found in my own research. }\end{array}$ \\
\hline \multicolumn{2}{|c|}{ Reflection } \\
\hline & In a perfect school library: \\
\hline $\begin{array}{l}\text { I would like to think about the world when I } \\
\text { am in and outside of the library. }\end{array}$ & $\begin{array}{l}\text { I would like to think about the world in and } \\
\text { out of the library. }\end{array}$ \\
\hline $\begin{array}{l}\text { New learning would help me ask questions } \\
\text { about the world when I am in and outside of } \\
\text { the library. }\end{array}$ & $\begin{array}{l}\text { New learning would help me ask questions } \\
\text { when I am in and out of the library. }\end{array}$ \\
\hline $\begin{array}{l}\text { I would like to think about how asking } \\
\text { questions is a part of life when I am in and } \\
\text { outside of the library. }\end{array}$ & $\begin{array}{l}\text { I would like to think about how asking } \\
\text { questions is a part of life when I am in and } \\
\text { out of the library. }\end{array}$ \\
\hline $\begin{array}{l}\text { I would learn interesting things about the world } \\
\text { when I am in and outside of the library. }\end{array}$ & $\begin{array}{l}\text { I would learn interesting things about the } \\
\text { world when I am in and out of the library. }\end{array}$ \\
\hline
\end{tabular}

The results for both years were analyzed using statistical methods to identify the gaps between what is preferred and what is actually occurring. The data were first analyzed against the learning environment dimensions for the school library environment with paired sample t-test analysis to compare the means for each grade's preferred environment to the actual learning environment as perceived by the students. The second application of data analysis involved using Pearson $r$ for a correlation among the scales measured by the MCI 
and a correlation with the homeroom teacher, school last attended, number of languages spoken, home country, and grade level. The results of these assessments follow.

\section{Results}

The results indicate some consistent perceptions and new variations between the first assessment in the 2010-2011 school year and the 2011-2012 school year. The statistical analysis results are presented for the lower school LMC area of responsibility.

Lower School LMC t-Test Analyses

The data was first analyzed with all three elementary grades combined. This cumulative approach, presented in Tables 3 and 4, provides a snapshot of the area of responsibility for the lower school LMC.

Table 3: 2010-2011 All participants' Preferred and Actual scales compared using paired sample t-test.

\begin{tabular}{|l|c|c|c|c|c|}
\hline & \multicolumn{2}{|c|}{ Means } & \multicolumn{2}{c|}{ Standard Deviations } & \\
\hline Scales & Preferred & Actual & Preferred & Actual & t-test \\
\hline Reflection & 2.20 & 2.16 & .42 & .44 & -0.81 \\
\hline Librarian Support & 2.37 & 2.35 & .38 & .43 & -0.45 \\
\hline Involvement & 2.29 & 2.00 & .41 & .38 & $-6.26^{*}$ \\
\hline Investigation & 2.34 & 2.16 & .42 & .43 & $-3.71^{*}$ \\
\hline Task Orientation & 2.52 & 2.59 & .42 & .40 & 1.35 \\
\hline Cooperation & 2.38 & 2.31 & .49 & .39 & -1.29 \\
\hline Equity & 2.54 & 2.53 & .50 & .48 & -0.13 \\
\hline
\end{tabular}

${ }^{*} \alpha=0.05, d f=91$

In the 2010-2011 school year, elementary students indicated that they preferred more involvement and investigation opportunities in their learning environment than they were currently receiving.

Table 4: 2011-2012 All participants' Preferred and Actual scales compared using paired sample t-test.

\begin{tabular}{|l|c|c|c|c|c|}
\hline & \multicolumn{2}{|c|}{ Means } & \multicolumn{2}{c|}{ Standard Deviations } & \\
\hline Scales & Preferred & Actual & Preferred & Actual & t-test \\
\hline Reflection & 2.30 & 2.30 & .41 & .43 & 0.12 \\
\hline Librarian Support & 2.45 & 2.34 & .48 & .48 & $-2.04^{*}$ \\
\hline Involvement & 2.33 & 2.06 & .37 & .45 & $-5.01^{*}$ \\
\hline Investigation & 2.54 & 2.40 & .35 & .42 & $-2.98^{*}$ \\
\hline Task Orientation & 2.60 & 2.61 & .42 & .39 & 0.30 \\
\hline Cooperation & 2.47 & 2.30 & .41 & .44 & $-3.45^{*}$ \\
\hline Equity & 2.61 & 2.53 & .42 & .48 & -1.48 \\
\hline
\end{tabular}

${ }^{*} \alpha=0.05, d f=91$ 
In the 2011-2012 school year elementary students continued to indicate that they would prefer more involvement and investigation opportunities than they perceive they actually receive. And, they added librarian support and cooperation as dimensions they would prefer to see increased.

To further explore student perceptions in the elementary grades, each grade level was examined separately. In the 2010-2011 school year, grades three, four and five exhibited the student perceptions that they would prefer more involvement than they were experiencing at a significant level. Cumulatively, the elementary grades indicated the desire for more investigation, but no single grade demonstrated this perception at a high enough level of significance to be representative in any grade. The following tables examine the individual elementary grades in the 2011-2012 school year to mine the data for grade level differences.

Table 5: 2011-2012 Grade 3 participants Preferred and Actual scales compared using paired sample t-test.

\begin{tabular}{|c|c|c|c|c|c|}
\hline & \multicolumn{2}{|c|}{ Means } & \multicolumn{2}{|c|}{ SD } & \\
\hline Scales & Preferred & Actual & Preferred & Actual & t-test \\
\hline Reflection & 2.28 & 2.24 & 0.47 & 0.39 & -0.51 \\
\hline Librarian Support & 2.43 & 2.23 & 0.49 & 0.44 & -2.19 \\
\hline Involvement & 2.29 & 1.91 & 0.31 & 0.47 & $-4.44 *$ \\
\hline Investigation & 2.46 & 2.25 & 0.39 & 0.46 & $-2.33^{*}$ \\
\hline Task Orientation & 2.58 & 2.66 & 0.46 & 0.40 & 0.80 \\
\hline Cooperation & 2.53 & 2.25 & 0.36 & 0.49 & $-3.42 *$ \\
\hline Equity & 2.61 & 2.45 & 0.39 & 0.47 & -1.53 \\
\hline
\end{tabular}

${ }^{*} \alpha=0.05, \mathrm{df}=47$

For grade three participants in the 2011-2012 school year there are four dimensions of significance: librarian support, involvement, investigation and cooperation. In the 20102011 school year the grade three students identified involvement as the only dimension of significance. However, for the current year they also perceive less librarian support, investigation opportunities and cooperation than they would prefer.

Table 6: 2011-2012 Grade 4 participants Preferred and Actual scales compared using paired sample t-test.

\begin{tabular}{|c|c|c|c|c|c|}
\hline & \multicolumn{2}{|c|}{ Means } & \multicolumn{2}{|c|}{ SD } & \\
\hline Scales & Preferred & Actual & Preferred & Actual & t-test \\
\hline Reflection & 2.43 & 2.34 & 0.33 & 0.32 & -1.16 \\
\hline Librarian Support & 2.35 & 2.28 & 0.55 & 0.46 & -0.97 \\
\hline Involvement & 2.28 & 2.02 & 0.42 & 0.39 & $-2.65 *$ \\
\hline Investigation & 2.53 & 2.39 & 0.38 & 0.42 & -1.95 \\
\hline Task Orientation & 2.54 & 2.58 & 0.37 & 0.36 & 0.54 \\
\hline Cooperation & 2.45 & 2.34 & 0.49 & 0.41 & -1.14 \\
\hline Equity & 2.61 & 2.58 & 0.42 & 0.50 & -0.39 \\
\hline
\end{tabular}

$* \alpha=0.05, \mathrm{df}=47$ 
Grade four participants are consistent across both school years with desiring more involvement than they actually experience.

Table 7: 2011-2012 Grade 5 participants Preferred and Actual scales compared using paired sample t-test.

\begin{tabular}{|l|c|c|c|c|c|}
\hline & \multicolumn{2}{|c|}{ Means } & \multicolumn{2}{c|}{ SD } & \\
\hline Scales & Preferred & Actual & Preferred & Actual & t-test \\
\hline Reflection & 2.21 & 2.36 & 0.42 & 0.34 & $1.91^{*}$ \\
\hline Librarian Support & 2.56 & 2.53 & 0.37 & 0.51 & -0.34 \\
\hline Involvement & 2.43 & 2.23 & 0.37 & 0.43 & -2.00 \\
\hline Investigation & 2.63 & 2.57 & 0.26 & 0.33 & -0.76 \\
\hline Task Orientation & 2.66 & 2.59 & 0.43 & 0.40 & -1.09 \\
\hline Cooperation & 2.45 & 2.34 & 0.38 & 0.40 & -1.49 \\
\hline Equity & 2.61 & 2.58 & 0.46 & 0.49 & -0.41 \\
\hline
\end{tabular}

$*^{*} \alpha=0.05, \mathrm{df}=47$

Contrary to grades three and four, involvement is not identified by grade five students as a dimension of significance. Instead, for the 2011-2012 grade five classes the dimension of reflection surfaces as a dimension where students are actually experiencing more reflection than they prefer.

To determine if these perceptions were consistent for females and males, the data were analyzed on a gender basis. Tables 8 and 9 provide the information for females in each of the research study years.

Table 8: 2010-2011 Female participants'Preferred and Actual scales compared using paired sample t-test.

\begin{tabular}{|l|c|c|c|c|c|}
\hline & \multicolumn{2}{|c|}{ Means } & \multicolumn{2}{c|}{ Standard Deviations } & \\
\hline Scales & Preferred & Actual & Preferred & Actual & t-test \\
\hline Reflection & 2.20 & 2.12 & .36 & .42 & 1.41 \\
\hline Librarian Support & 2.40 & 2.39 & .41 & .43 & .29 \\
\hline Involvement & 2.29 & 2.01 & .45 & .41 & $4.15^{*}$ \\
\hline Investigation & 2.33 & 2.19 & .43 & .44 & 2.28 \\
\hline Task Orientation & 2.57 & 2.67 & .40 & .34 & -1.61 \\
\hline Cooperation & 2.39 & 2.32 & .49 & .40 & 1.05 \\
\hline Equity & 2.56 & 2.55 & .53 & .49 & .18 \\
\hline
\end{tabular}

${ }^{*} \alpha=0.05, \mathrm{df}=58$

Females in the 2010-2011 school year indicate that they would prefer more involvement than they are currently experiencing. 
Table 9: 2011-2012 Female participants' Preferred and Actual scales compared using paired sample t-test.

\begin{tabular}{|c|c|c|c|c|c|}
\hline & \multicolumn{2}{|c|}{ Means } & \multicolumn{2}{|c|}{ Standard Deviations } & \\
\hline Scales & Preferred & Actual & Preferred & Actual & t-test \\
\hline Reflection & 2.36 & 2.35 & 0.31 & 0.31 & -0.32 \\
\hline Librarian Support & 2.49 & 2.39 & 0.46 & 0.47 & -1.55 \\
\hline Involvement & 2.35 & 2.06 & 0.35 & 0.40 & $-3.98 *$ \\
\hline Investigation & 2.58 & 2.45 & 0.36 & 0.39 & -1.80 \\
\hline Task Orientation & 2.66 & 2.75 & 0.34 & 0.29 & 1.53 \\
\hline Cooperation & 2.53 & 2.40 & 0.35 & 0.38 & -1.64 \\
\hline Equity & 2.64 & 2.60 & 0.41 & 0.48 & -0.49 \\
\hline
\end{tabular}

${ }^{*} \alpha=0.05, \mathrm{df}=43$

Once again, females in the 2011-2012 school year indicate that they would prefer more involvement than they are currently experiencing. The analysis results for males are presented in Tables 10 and 11.

Table 10: 2010-2011 Male participants' Preferred and Actual scales compared using paired sample t-test.

\begin{tabular}{|l|c|c|c|c|c|}
\hline & \multicolumn{2}{|c|}{ Means } & \multicolumn{2}{c|}{ SD } & \\
\hline Scales & Preferred & Actual & Preferred & Actual & t-test \\
\hline Reflection & 2.21 & 2.23 & .46 & .44 & -.37 \\
\hline Librarian Support & 2.33 & 2.33 & .34 & .37 & .07 \\
\hline Involvement & 2.29 & 2.00 & .37 & .31 & $4.58^{*}$ \\
\hline Investigation & 2.34 & 2.16 & .40 & .37 & $2.72^{*}$ \\
\hline Task Orientation & 2.47 & 2.52 & .43 & .38 & -.75 \\
\hline Cooperation & 2.35 & 2.32 & .48 & .34 & .34 \\
\hline Equity & 2.52 & 2.55 & .47 & .41 & -.35 \\
\hline
\end{tabular}

$*_{\alpha}=0.05, \mathrm{df}=47$

During the 2010-2011 school year male participants indicated that they would prefer more involvement and investigation opportunities.

Table 11: 2011-2012 Male participants' Preferred and Actual scales compared using paired sample t-test.

\begin{tabular}{|c|c|c|c|c|c|}
\hline & \multicolumn{2}{|c|}{ Means } & \multicolumn{2}{|c|}{$\mathrm{SD}$} & \\
\hline Scales & Preferred & Actual & Preferred & Actual & t-test \\
\hline Reflection & 2.25 & 2.28 & 0.49 & 0.38 & 0.35 \\
\hline Librarian Support & 2.40 & 2.30 & 0.48 & 0.49 & -1.33 \\
\hline Involvement & 2.32 & 2.06 & 0.37 & 0.49 & $-3.18^{*}$ \\
\hline Investigation & 2.51 & 2.35 & 0.34 & 0.43 & $-2.39 *$ \\
\hline Task Orientation & 2.53 & 2.48 & 0.48 & 0.41 & -0.74 \\
\hline Cooperation & 2.42 & 2.21 & 0.44 & 0.46 & $-3.34 *$ \\
\hline Equity & 2.57 & 2.46 & 0.42 & 0.48 & -1.60 \\
\hline
\end{tabular}

${ }^{*} \alpha=0.05, \mathrm{df}=47$ 
During the 2011-2012 school year male participants again indicated that they would prefer more involvement and investigation opportunities. In addition, they perceive that there is less cooperation than they would prefer.

A deeper analysis by grade level revealed that there is consistency among grades in regards to gender during the 2010-2011 school year. But, it is grade three students in the 2011-2012 school year that demonstrate a wider range of dimensions between what is preferred and what they are experiencing. These results are presented in Tables 12 and 13.

Table 12: 2011-2012 Grade 3 female participants' Preferred and Actual scales compared using paired sample t-test.

\begin{tabular}{|l|c|c|c|c|c|}
\hline & \multicolumn{2}{|c|}{ Means } & \multicolumn{2}{c|}{ SD } & \\
\hline Scales & Preferred & Actual & Preferred & Actual & t-test \\
\hline Reflection & 2.36 & 2.27 & 0.40 & 0.32 & -1.14 \\
\hline Librarian Support & 2.47 & 2.34 & 0.47 & 0.34 & -1.07 \\
\hline Involvement & 2.28 & 1.98 & 0.33 & 0.44 & $-2.29^{*}$ \\
\hline Investigation & 2.48 & 2.34 & 0.46 & 0.41 & -0.88 \\
\hline Task Orientation & 2.56 & 2.77 & 0.41 & 0.25 & 1.67 \\
\hline Cooperation & 2.63 & 2.38 & 0.26 & 0.40 & $-2.39^{*}$ \\
\hline Equity & 2.50 & 2.50 & 0.44 & 0.46 & 0.00 \\
\hline
\end{tabular}

$* \alpha=0.05, \mathrm{df}=47$

For grade three female participants in the 2011-2012 school year the dimensions of significance are involvement and cooperation.

Table 13: 2011-2012 Grade 3 male participants' Preferred and Actual scales compared using paired sample t-test.

\begin{tabular}{|l|c|c|c|c|c|}
\hline & \multicolumn{2}{|c|}{ Means } & \multicolumn{2}{c|}{ SD } & \\
\hline Scales & Preferred & Actual & Preferred & Actual & t-test \\
\hline Reflection & 2.20 & 2.11 & 0.53 & 0.45 & 0.12 \\
\hline Librarian Support & 2.39 & 2.22 & 0.52 & 0.50 & -1.92 \\
\hline Involvement & 2.30 & 1.83 & 0.29 & 0.50 & $-4.11^{*}$ \\
\hline Investigation & 2.44 & 2.16 & 0.32 & 0.50 & 0.00 \\
\hline Task Orientation & 2.59 & 2.55 & 0.51 & 0.48 & -0.31 \\
\hline Cooperation & 2.44 & 2.13 & 0.42 & 0.55 & $-2.40^{*}$ \\
\hline Equity & 2.72 & 2.39 & 0.31 & 0.48 & $-2.31^{*}$ \\
\hline
\end{tabular}

$* \alpha=0.05, \mathrm{df}=47$

Male participants in grade three for the 2011-2012 school year mirror the females with identification of involvement and cooperation as dimensions of significance but they also indicate a significant gap between the equity they prefer and what they are actually experiencing. 


\section{Lower School LMC Pearson r Correlations}

A correlation shows a relationship between two variables. There is no causation tested, only the strength of the relationship. Correlations are also used to determine a relationship where one variable becomes more positive as another one does, or if one variable becomes positive as another becomes negative. Each school year is examined for the relationship between variables. Tables 14 and 15 examine the 2010-2011 school year.

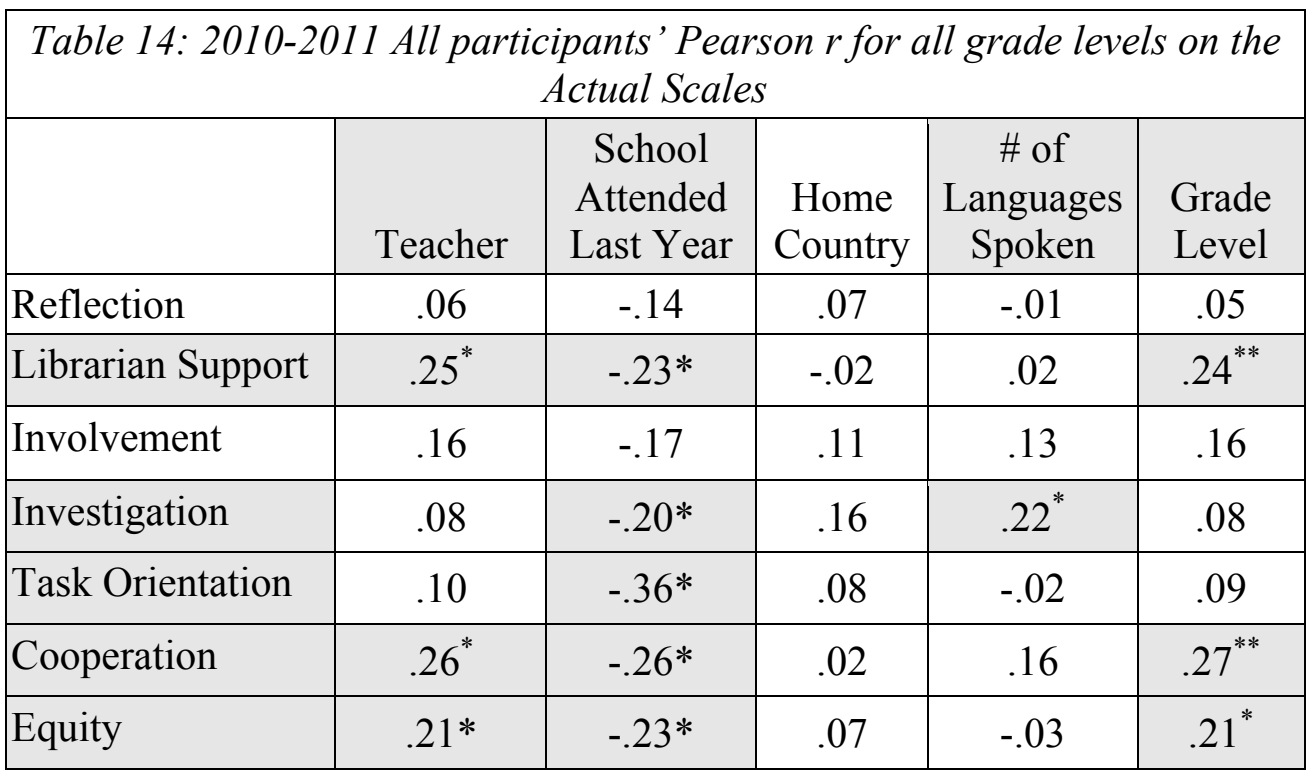

$*_{\alpha}=0.05, * * \alpha=0.01, \mathrm{r}$ critical value $=.197$

There are significant correlations among several of the situational demographic items and the scales on the Actual form of the questionnaire. These include positive correlations between Teacher and Librarian Support, Teacher and Cooperation, and Teacher and Equity. This may indicate that the teacher and the librarian work closely together to help students experience inquiry; it may also indicate that in some teachers' classes the students experience a high level of cooperation and equity. For School Attended Last Year there is a negative correlation with Librarian Support, Investigation, Task Orientation, Cooperation and Equity. This could indicate the impact of transitioning to a new school. The Number of Languages Spoken is positively correlated with Investigation; this could relate to the intensity of inquiry when learning new languages. There are positive correlations between Grade Level and Librarian Support, Cooperation and Equity. This may mean that as students get more school experience, they are better able to evaluate and articulate the extent to which each of these scales is present. The extent to which these relationships differ by gender is presented in Table 15. 


\begin{tabular}{|c|c|c|c|c|c|}
\hline \multicolumn{6}{|c|}{$\begin{array}{c}\text { Table 15: 2010-2011 All participants' Pearson r for all grade levels on the Actual } \\
\text { Scales parsed by gender }\end{array}$} \\
\hline & Teacher & \begin{tabular}{|c|} 
School \\
Attended Last \\
Year
\end{tabular} & $\begin{array}{l}\text { Home } \\
\text { Country }\end{array}$ & $\begin{array}{c}\# \text { of } \\
\text { Languages } \\
\text { Spoken }\end{array}$ & Grade Level \\
\hline \multicolumn{6}{|l|}{ Females } \\
\hline Reflection & 0.22 & -0.03 & -0.00 & -0.01 & 0.21 \\
\hline Librarian Support & 0.21 & 0.05 & -0.06 & 0.13 & 0.21 \\
\hline Involvement & 0.07 & 0.07 & 0.17 & 0.17 & 0.07 \\
\hline Investigation & 0.12 & 0.09 & 0.15 & 0.23 & 0.13 \\
\hline Task Orientation & -0.01 & -0.03 & 0.19 & -0.07 & -0.03 \\
\hline Cooperation & $0.30 * *$ & -0.24 & 0.00 & 0.18 & $0.31 * *$ \\
\hline Equity & $0.29 * *$ & 0.22 & 0.02 & -0.06 & $0.28 * *$ \\
\hline \multicolumn{6}{|l|}{ Males } \\
\hline Reflection & -0.11 & 0.06 & 0.13 & 0.01 & -0.12 \\
\hline Librarian Support & $0.31 * *$ & -0.05 & 0.00 & -0.26 & $0.31 * *$ \\
\hline Involvement & $0.30 * *$ & -0.01 & -0.00 & 0.02 & $0.29 * *$ \\
\hline Investigation & 0.02 & -0.06 & 0.16 & 0.18 & 0.02 \\
\hline Task Orientation & 0.24 & -0.18 & -0.07 & 0.03 & 0.23 \\
\hline Cooperation & 0.24 & -0.00 & 0.01 & 0.07 & 0.25 \\
\hline Equity & 0.11 & -0.10 & 0.12 & -0.03 & 0.12 \\
\hline
\end{tabular}

${ }^{*} \alpha=0.05, *^{*} \alpha=0.01, \mathrm{df}$ females $=58, \mathrm{r}$ critical value females $=.25, \mathrm{df}$ males $=$ $47, \mathrm{r}$ critical value males $=.28$

When the data results from the Actual instrument are examined more closely, it becomes apparent that the males and females are experiencing differing perceptions. For the females, there is a positive correlation between the Teacher and students' perceptions of Cooperation and Equity; the girls feel they are being treated equally. There are also positive correlations between Grade Level and Cooperation and Equity. This may mean that as students get more school experience, they are better able to evaluate the extent to which each of these scales is present.

For males, the teacher also seems to be a determining factor influencing perceptions of the actual learning environment. Teachers are positively correlated with Librarian Support, and Involvement. There are also positive correlations between Grade Level and Librarian Support and Involvement. This may mean that a combination of homeroom teacher and grade level of experience correlate to appreciation of librarian support and a feeling of involvement. The differences for school year 2011-2012 are presented in Tables 16 and 17. 


\begin{tabular}{|l|c|c|c|c|c|}
\hline \multicolumn{7}{|c|}{ Table 16: 2011-2012 All participants' Pearson r for all grade levels on the } \\
Actual Scales
\end{tabular}

$* \alpha=0.05, * * \alpha=0.01, \mathrm{r}$ critical value $=.197$

The significant correlations among several of the situational demographic items and the scales on the Actual form of the questionnaire include a positive correlation between Grade Level and Teacher with Librarian Support, Involvement, and Investigation. Unlike the previous school year, there is only one negative correlation with School Last Attended and that is with Task Orientation. Also unlike the previous school year there are no correlations with the number of languages spoken. The extent to which these relationships differ by gender is presented in Table 16.

\begin{tabular}{|c|c|c|c|c|c|}
\hline \multicolumn{6}{|c|}{$\begin{array}{c}\text { Table 17: 2011-2012 All participants' Pearson r for all grade levels on the Actual } \\
\text { Scales parsed by gender }\end{array}$} \\
\hline & Teacher & $\begin{array}{c}\text { School } \\
\text { Attended Last } \\
\text { Year }\end{array}$ & $\begin{array}{l}\text { Home } \\
\text { Country }\end{array}$ & $\begin{array}{c}\# \text { of } \\
\text { Languages } \\
\text { Spoken }\end{array}$ & Grade Level \\
\hline \multicolumn{6}{|l|}{ Females } \\
\hline Reflection & 0.19 & $0.31^{* *}$ & 0.25 & 0.07 & 0.19 \\
\hline Librarian Support & 0.19 & 0.00 & 0.18 & 0.23 & 0.18 \\
\hline Involvement & 0.25 & 0.12 & 0.05 & -0.05 & 0.24 \\
\hline Investigation & $0.28 * *$ & 0.25 & 0.07 & -0.03 & $0.28 * *$ \\
\hline Task Orientation & 0.11 & 0.19 & 0.05 & 0.00 & 0.09 \\
\hline Cooperation & 0.10 & 0.05 & -0.10 & -0.04 & 0.10 \\
\hline Equity & 0.17 & 0.10 & 0.01 & 0.19 & 0.15 \\
\hline \multicolumn{6}{|l|}{ Males } \\
\hline Reflection & 0.10 & -0.08 & -0.05 & 0.14 & 0.10 \\
\hline Librarian Support & $0.34^{* *}$ & 0.13 & -0.05 & 0.11 & $0.33 * *$ \\
\hline Involvement & $0.34 * *$ & 0.08 & -0.04 & 0.24 & $0.34 * *$ \\
\hline
\end{tabular}




\begin{tabular}{|l|c|c|c|c|c|}
\hline Investigation & $0.35^{* *}$ & -0.17 & 0.14 & 0.07 & $0.35^{* *}$ \\
\hline Task Orientation & -0.18 & -0.27 & -0.02 & 0.01 & -0.18 \\
\hline Cooperation & 0.07 & -0.11 & -0.04 & 0.08 & 0.06 \\
\hline Equity & 0.08 & 0.11 & -0.16 & -0.03 & 0.08 \\
\hline
\end{tabular}

${ }^{*} \alpha=0.05,{ }^{* *} \alpha=0.01, \mathrm{df}$ females $=59, \mathrm{r}$ critical value females $=.281, \mathrm{df}$ males $=48, \mathrm{r}$ critical value males $=.294$

As with the previous school year, males and females are experiencing differing perceptions. For the females, there is a positive correlation between the Teacher and students' perception of Investigation and between Grade Level and Investigation. There is also a significant positive correlation between School Last Attended and Reflection. For males, the Teacher and Grade Level once again correlate positively with Librarian Support and Involvement. However, in this school year, Investigation also shows a positive correlation with Teacher and Grade Level. The implications of these results will be discussed in the following section.

\section{Discussion}

The research results provide evidence of the relationship between school libraries and student learning impacts, as previously demonstrated by Schultz-Jones and Ledbetter $(2009,2010 \mathrm{a}, 2010 \mathrm{~b})$ in a series of studies in a north Texas school district. The arena of personal interaction between school librarians and students may be most influential in affecting student outcomes. Engendering enthusiasm for learning relates to a constructivist learning environment, one which is learner-centered and encourages the learner to construct knowledge through experiences. Within a constructivist school library learning environment this encouragement relates to the personal behaviour and educational values the school librarian exhibits.

For the Lower School LMC, there are several findings of significance. For each of these, it would be worthwhile to further explore the responses with student interviews. This would assist with confirmation and clarification of the interpretation of the results. And, discussions with the teachers would also provide new opportunities for collaboration as the feedback is reviewed and new strategies for interaction are devised.

In both school years, elementary students indicated that they preferred more involvement and investigation opportunities in their learning environment than they were currently receiving. On the surface, this suggests that students are not content with what they are experiencing. However, this could be an indicator that students enjoy working and learning in the LMC and are simply looking for more of a good thing. The library has many popular titles and circulation numbers indicate that students enjoy coming for free-choice check-out. They may not be distinguishing between "research" as given in school assignments and the personal inquiry they engage in when free to make their own choices. In the school library program under study, students commonly have a choice even in their assigned topics and projects. It is possible that this finding simply quantifies their natural curiosity.

When each grade level was examined separately to further explore perceptions it was found that for grade three participants in the 2011-2012 school year there are four dimensions of significance: librarian support, involvement, investigation and cooperation. In 
the 2010-2011 school year the grade three students identified involvement as the only dimension of significance. However, for the current year they also perceive less librarian support, investigation opportunities and cooperation than they would prefer. When the data was examined by gender, the primary difference of note is the grade three males and the difference between the amount of equity they prefer and what they are actually experiencing.

It is not surprising that the grade three students experience a wider range of responses across several of the survey dimensions. One reason for this could be that the grade three students are learning the basics of how to conduct research. In the library, classes through grade two often receive a story time or literature extension activity. However, beginning in grade three more instruction is given using reference and information materials. This may take some of the students by surprise. Also, because the students are younger, there is less experience in a school library and a wider range of expectations about what the students would like to happen in the LMC. This is a pivotal time for these students and the feedback suggests that they have yet to reach a comfort level with these new challenges. The feedback can be viewed as positive in that respect, but also indicates an opportunity for the teachers and school librarian to work further with these students as they respond to new learning directions. The equity response by grade three males is also worth considering in terms of the grade three introductions to new information materials, with attention to how males are responding in comparison to the females.

Grade four participants consistently desired more involvement than they actually experience. In the school library program under study, the librarian offers less support to grade four than to grades three and five. This is the homeroom teachers' choice and reflects a more self-contained program in grade four. Fewer library lessons are given to these students because the teachers quite often spend library time with students working on literature projects in class. The results indicate that more library time would be preferred and this feedback would provide an opportunity for the grade four teachers and school librarian to reflect and collaborate on addressing this perception.

Contrary to grades three and four, involvement was not identified by grade five students as a dimension of significance. Instead, for the 2011-2012 grade five classes the dimension of reflection surfaces as a dimension where students are actually experiencing more reflection than they prefer. In the library program under study, the librarian works more closely with grade five students than with other grades. The research process (Big 6), source evaluation, and citation creation are taught throughout the year in preparation for the culminating grade five Exhibition project. "Exhibition" is a Primary Years Program event in which students prepare a comprehensive individual inquiry project. The students build up to this project all year and the librarian works closely with them, giving instruction and feedback on a regular basis. Due to the focused attention from the librarian throughout the year, it is not surprising that the Grade 5 students do not feel the need for more involvement. And with the emphasis on an inquiry project, it is also not surprising that they are experiencing more reflection opportunities than they expect.

Correlation analyses indicating positive correlations between Teacher and Librarian Support, Teacher and Cooperation, and Teacher and Equity suggest that the teacher extends a significant influence over student perceptions. The correlations also suggest that the teacher and the librarian work closely together to help students experience inquiry, given the high level of collaboration between the school librarian and teachers in grades three and five. For 
males, the teacher also seems to be a determining factor influencing perceptions of the actual learning environment. With the positive correlations between Grade Level and Librarian Support and Involvement for males, it may be that a combination of homeroom teacher and grade level of experience correlate to appreciation of librarian support and a feeling of involvement. This influence is not surprising but does reinforce the need to consider teacher and school librarian interactions when developing approaches to advance student achievement.

A significant consideration for international schools is the correlations for School Attended Last Year and the Number of Languages Spoken. The negative correlations for School Attended Last Year with Librarian Support, Investigation, Task Orientation, Cooperation and Equity could indicate the impact of transitioning to a new school. Making this transition to a new school is an experience that affects a high number of students in this international school. Table 17 presents the student turnover data for the years of study.

Table 17. Student Turnover

\begin{tabular}{|c|c|c|c|c|c|}
\hline \multicolumn{3}{|c|}{$2010-2011$} & \multicolumn{3}{|c|}{2012} \\
\hline $\begin{array}{c}\text { Total } \\
\text { Students }\end{array}$ & $\begin{array}{l}\text { From Current } \\
\text { School }\end{array}$ & $\begin{array}{c}\text { From Previous } \\
\text { School }\end{array}$ & $\begin{array}{c}\text { Total } \\
\text { Students }\end{array}$ & $\begin{array}{c}\text { From Current } \\
\text { School }\end{array}$ & $\begin{array}{c}\text { From Previous } \\
\text { School }\end{array}$ \\
\hline \multicolumn{3}{|c|}{ 3rd Grade } & \multicolumn{3}{|c|}{ 3rd Grade } \\
\hline 33 & 29 & 4 & 32 & 29 & 3 \\
\hline $100.00 \%$ & $87.88 \%$ & $12.12 \%$ & $100.00 \%$ & $90.63 \%$ & $9.38 \%$ \\
\hline \multicolumn{3}{|c|}{ 4th Grade } & \multicolumn{3}{|c|}{ 4th Grade } \\
\hline 36 & 27 & 9 & 28 & 24 & 4 \\
\hline $100.00 \%$ & $75.00 \%$ & $25.00 \%$ & $100.00 \%$ & $85.71 \%$ & $14.29 \%$ \\
\hline \multicolumn{3}{|c|}{ 5th Grade } & \multicolumn{3}{|c|}{ 5th Grade } \\
\hline 39 & 36 & 3 & 32 & 19 & 13 \\
\hline $100.00 \%$ & $92.31 \%$ & $7.69 \%$ & $100.00 \%$ & $59.38 \%$ & $40.63 \%$ \\
\hline
\end{tabular}

In the 2010-2011 school year, for example, $25 \%$ of grade four students were new to this international school. And in the 2011-2012 school year, 40.6\% of grade five students joined this international school for the first time. This rate of turnover is significant in terms of the potential for limiting the impact of interventions from year to year, and challenging in terms of finding the level of sensitivity to these student variables. An interesting correlation is the Number of Languages Spoken positively correlating with Investigation. The intensity of acquiring a new language(s) may signify an intensity of inquiry that influences the orientation to investigation. This correlation could be explored further as students and teachers are interviewed in a future phase of the research.

Instruction and learning are integral to school library programs. Tools that enable constructive assessment of the learning environments associated with these programs could enable improvement of teaching methods and relationships between students, teachers and school librarians. This evidence in practice will further contribute to recognition of the strong role of the school library program in the school learning community. 


\section{Conclusion}

The purpose of learning environment research is to allow students to describe their perceptions of and preferences for the interactions among the students, teachers and curriculum. Knowledge of these perceptions can contribute to understanding student needs and lead to improvements in the school library learning environment and by extension evidence of practice through student achievement. The evolution of this learning environment could also include enhanced interaction between school librarians and classroom teachers.

The cycle of learning environment assessment involves data collection, data analysis, reflection on the results alone and with teachers and students, consideration of changes or modifications to either behavior or opportunities for students, change implementation, and reassessment. Use of these instruments in this study of the psychosocial aspects of the learning environment offers valuable ideas for the focus of techniques for teacher development and incorporation by school librarians. By gaining insight into student perceptions, the potential exists to consider ways to guide changes aimed at aligning the actual learning environment with the preferred learning environment. While the reflections and recommendations relate to one specific international school, aspects of inquiry and behavioral factors could be generalizable to other international schools. Future research will pursue additional opportunities in additional international schools.

\section{References}

Fraser, B.J. (1998a). The birth of a new journal: Editor's introduction. Learning Environments Research, 1, 1-5.

Fraser, B.J. (1998b). Classroom environment instruments: Development, validity and applications. Learning Environments Research, 1, 7-33.

Fraser, B.J. (1998c). Science learning environments: Assessment, effects and determinants. In B.J. Fraser, \& K.G. Tobin, (Eds.), International Handbook of Science Education (pp. 527-564). Dordrecht, The Netherlands: Kluwer Academic Publishers.

Fraser, B.J. (2002). Learning environments research: Yesterday, today and tomorrow. In S.C. Goh, \& M.S. Khine (Eds.), Studies in Educational Learning Environments: An International Perspective (pp. 1-25). Singapore: World Scientific.

Fraser, B.J. (2007). Classroom learning environments. In S.K. Abell, \& N.G. Lederman (Eds.), Handbook of Research on Science Education (pp. 103-124). Mahwah, NJ: Lawrence Erlbaum.

Fraser, B.J., \& O'Brien, P. (1985). Student and teacher perceptions of the environment of elementary-school classrooms. Elementary School Journal, 85, 567-580.

Goh, S.C., Young, D.J. \& Fraser, B.J. (1995). Psychosocial climate and student outcomes in elementary mathematics classrooms: A multilevel analysis. Journal of Experimental Education, 64, 29-40.

ISC Research (2012). Mapping the world of international schools. Available at: http://www.iscresearch.com/

Lance, K.C., Hamilton-Pennell, C., Rodney, M.J., Peterson, L., \& Sitter, C. (2000). Information empowered: The school librarian as an agent of academic achievement in Alaska schools. Juneau: Alaska State Library. 
Lance K.C., Rodney, M.J., \& Hamilton-Pennell, C. (2000a). How school librarians help kids achieve standards: The second Colorado study. Denver: Colorado State Library, Colorado Board of Education.

Lance K.C., Rodney, M.J., \& Hamilton-Pennell, C. (2000b). Measuring up to standards: The impact of library programs \& information literacy in Pennsylvania schools. Harrisburg: Pennsylvania Department of Education.

Lance K.C., Rodney, M.J., \& Hamilton-Pennell, C. (2001). Good schools have good librarians: Oregon school librarians collaborate to improve student achievement. Portland: Oregon Educational Media Association.

Lance K.C., Rodney, M.J., \& Hamilton-Pennell, C. (2002). How school libraries improve outcomes for children: The New Mexico study. Santa Fe: New Mexico State Library.

Lance K.C., Welborn, L., \& Hamilton-Pennell, C. (1997). The impact of school media centers on academic achievement. Castle Rock, CO: Hi Willow Research.

Lewin, K. (1936). Principles of topological psychology. New York: McGraw.

Lorsbach, A. \& Basolo, F. (1998). Collaborating in the evolution of a middle school science learning environment. Learning Environments Research, 1(1), 115-127.

Maor, D., \& Fraser, B.J. (1996). Use of classroom environment perceptions in evaluating inquiry-based computer-assisted learning. International Journal of Science Education, 18, 401-421.

Martin-Dunlop, C. S., \& Fraser, B. J. (2008). Learning environment and attitudes associated with an innovative science course designed for prospective elementary teachers. International Journal of Science and Mathematics Education, 6(1), 163-190.

McRobbie, C. J., \& Fraser, B. J. (1993). Associations between student outcomes and psychosocial science environment. Journal of Educational Research, 87, 78-85.

Monsen, J. J., \& Frederickson, N. (2004). Teachers' attitudes towards mainstreaming and their pupils' perceptions of their classroom learning environment. Learning Environments Research 7, 129-142.

Moos, R. H. (1974). Classroom Environment Scale manual. Palo Alto, CA: Consulting Psychologists Press.

Murray, H. A. (1938). Explorations in personality. New York: Oxford University Press.

Nix, R.K., Ledbetter, C.E., \& Fraser, B.J. (2001, December). Evaluation of an integrated science learning environment that bridges university field classes and field trips.

Paper presented at the annual meeting of the Australian Association for Research in Education, Fremantle, Australia.

Ogbuehi, P. I., \& Fraser, B. J. (2007). Learning environment, attitudes and conceptual development associated with innovative strategies in middle-school mathematics. Learning Environments Research, 10, 101-114.

Pollock, D.C. \& Van Reken, R.E. (2001). Third culture kids: The experience of growing up among worlds. Boston: Nicholas Brealey Publishing.

Schultz-Jones, B., \& Ledbetter, C. (2009). School libraries as learning environments: Examining elementary and middle school students' perceptions. Research Paper in the Proceedings of the $13^{\text {th }}$ International Forum on Research in School Librarianship at the $38^{\text {th }}$ International Association of School Librarianship Annual Conference, Padua, Italy, September 2-4, 2009. 
Schultz-Jones, B., \& Ledbetter, C. (2010a). Assessing school libraries as learning environments: Examining students' perceptions in grades three, four and five. Research Paper in the Proceedings of the $14^{\text {th }}$ International Forum on Research in School Librarianship at the $39^{\text {th }}$ International Association of School Librarianship Annual Conference, Brisbane, Australia, September 27-30, 2010.

Schultz-Jones, B., \& Ledbetter, C. (2010b). Investigating third through sixth grade students' perceptions of school library learning environments. Research Paper in the Proceedings of the American Educational Research Association Annual Meeting, Denver, Colorado, April 30 - May 4, 2010.

Schultz-Jones, B. \& Ledbetter, C. (2012 in press). Exploring literacy through library and science inquiry: Validation of two new learning environment questionnaires. Learning Environments Research.

Smith, E. (2001). Texas school libraries: Standards, resources, services, and students' performance. Austin, TX: Texas State Library and Archives Commission.

Taylor, P., Fraser, B., \& Fisher, D. (1997). Monitoring constructivist classroom learning environments. International Journal of Educational Research, 27, 293-302.

Tobin, K., \& Fraser, B.J. (1998). Qualitative and quantitative landscapes of classroom learning environments. In B.J. Fraser \& K.G. Tobin (Eds.), International handbook of science education (pp. 623-640). Dordrecht, The Netherlands: Kluwer.

Todd, R. (2009). School librarianship and evidence based practice: Progress, perspectives, and challenges. Evidence Based Library and Information Practice, 4(2), 78-96.

Todd, R.J. \& Kuhlthau, C.C. (2004). Student learning through Ohio school libraries. Ohio Educational Library Media Association. Available at: http://www.oelma.org/studentlearning/.

\section{Author Note}

Barbara Schultz-Jones is an Associate Professor in the Department of Library and Information Sciences in the College of Information (COI), University of North Texas. She has published and taught in the areas of Information Literacy, Cataloging and Classification, Library Automation, Learning Environments and Social Network Analysis. Barbara is an active member of the Research and Statistics Committee for the American Association of School Librarians (AASL). As the International Association of School Librarianship (IASL) representative on the International Federation of Library Associations (IFLA) Section on School Libraries and Resource Centers she became Secretary of the Section in August, 2011.

Betty Turpin is the Lower School librarian at the Degerloch campus of the International School of Stuttgardt, a CIS/NEASC-accredited, IB World School. She works with students and teachers from Pre-kindergarten through grade five. As a recent graduate of the University of North Texas she maintains her focus on emerging trends in education through research and avid reading.

Cynthia Ledbetter is Professor Emeritus of Science and Mathematics Education at the University of Texas at Dallas. She has extensive experience with learning environment research in the science classroom and has moved this research to the school library learning environment in recent years. Cynthia has participated in studies related to the correlation 
between science and library learning environments and guides the statistical analysis for these research studies. 